\title{
Existence of solutions for impulsive fractional integrodifferential equations involving Gronwall's inequality in Banach spaces
}

\section{A. Al-OMARI, M. H. M. RASHID and K. KARTHIKEYAN}

\section{ABSTRACT.}

In this paper, we study boundary value problems for impulsive fractional integrodifferential equations involving Caputo derivative in Banach spaces. A generalized singular type Gronwall inequality is given to obtain an important priori bounds. Some sufficient conditions for the existence solutions are established by virtue of fractional calculus and fixed point method under some mild conditions.

DEPARTMENT OF MATHEMATics

AL AL-BAYT UNIVERSITY

FACULTY OF SCIENCES

P.O. BOX 130095, MAFRAQ 25113, JORDAN

E-mail address: omarimutah1@yahoo.com

DEPARTMENT OF MATHEMATICS AND STATISTICS

MUTAH UNIVERSITY

FACULTY OF SCIENCE

P.O. BOX (7), AL-KARAK, JORDAN

E-mail address: malik_okasha@yahoo.com

DEPARTMENT OF MATHEMATICS

COLlEGE OF TECHNOLOGY

TIRUCHENGODE-637215, TAMILNADU

KSR COLLEGE OF TECHNOLOGY, INDIA

E-mail address: karthi_phd2010@yahoo.co.in 